\title{
Port governance revisited: How to govern and for what purpose?
}

\author{
Qiang Zhang ${ }^{\mathrm{a}}$, Shiyuan Zheng ${ }^{\mathrm{a}, *}$, Harry Geerlings ${ }^{\mathrm{b}}$, Abdel El Makhloufi ${ }^{\mathrm{c}}$ \\ ${ }^{a}$ College of Transport and Communications, Shanghai Maritime University, Shanghai, 201306, China \\ ${ }^{\mathrm{b}}$ Erasmus School of Social and Behavioural Sciences, Erasmus Smart Port, Erasmus University Rotterdam, Rotterdam, 3062 PA, Netherlands \\ ${ }^{\mathrm{c}}$ Smart Mobility \& Logistics, Research Programme Urban Technology, Amsterdam University of Applied Sciences, Amsterdam, Netherlands
}

\section{A R T I C L E I N F O}

\section{Keywords:}

Port governance

Governance tool

Port performance

Port efficiency

Port effectiveness

\begin{abstract}
A B S T R A C T
This review paper investigates and presents generalized answers to the two basic questions of port governance, namely how to govern and for what purpose. The study is based on a total sample of 118 studies on port governance. The results from the analysis of these studies show that port devolution and port re-centralization are the main governance tools at the institutional level. At the strategical level, the main governance tools are port co-opetition, port regionalization, port integration, stakeholder management strategy, and corporate governance. While at the managerial level, the main governance tools are port pricing, port concession, port user/ customer relationship management, monitoring and measuring, regulatory control, port security management, and information and communication technologies. The institutional governance tools are generally used by governmental organizations to set the fundamental regulative rules for the port governance system, while strategical tools are applied by port organizations in gaining competitive advantages and increasing market share in the long term. Managerial tools are related to the port business operations and management. Furthermore, The study clearly shows that the main objective of port governance is the improvement of port efficiency and port effectiveness. However, the choice of efficiency-oriented or effectiveness-oriented configuration is largely determined by the port organization's external operating environment, strategies and structures.
\end{abstract}

\section{Introduction}

Since the 1990s, port governance has attracted much attention from the academic, the port authorities, as well as the policy and decision makers operating in the maritime sector, and port governance itself has gradually became an important academic and practical concept in the port field. Although a lot of studies have been published on the topic of port governance, there exists no consensus on the definition of port governance because of the complexity and vagueness of the scope of governance. To the best of our knowledge, the definition of port governance proposed by Brooks and Pallis (2012: p.512) is relatively complete, which states that "governance is the adoption and enforcement of rules governing conduct and property rights ...... in the case of ports, governments, or other relevant policy makers, usually impose governance structure with particular national or regional policy objectives in mind ......". Despite extensive analyses of port governance, the four basic questions surrounding the port governance, namely who governs, what is governed, how is it governed, and for what purpose are still unanswered (Vieira et al., 2014). To fill this gap, Zhang et al. (2018) conducted an intensive review study that gives answers to the first two questions (i.e. who governs? what is governed?) of port governance. In the study by Zhang et al. (2018), governmental organizations and port organizations are identified as the main governing actors, and twelve different groups of specific port activities, classified within five categories, are identified as governed objects in port governance.

The present paper is complementary to the study of Zhang et al. (2018) and tries to find answers to other two remaining questions on port governance (i.e. how is it governed? and for what purpose?). In this paper, we mark the two questions as "how to govern" and "govern for what". Close to our study, Notteboom (2006) provides a comprehensive discussion on the role of concession agreements as a port governance tool under the landlord port model. Sorour and AbdulMageed (2016) articulate that information and communication technologies (ICTs) function as a pillar for enhancing port governance. Brooks and Cullinane (2006) clearly point out that governments develop port governance models to potentially maximize the desired performance outcomes. Lam and Notteboom (2014) present various tools that leading Asian and European ports adopt for the development of green port strategies and social responsibility.

However, up to date, the existing literature on port governance do

\footnotetext{
* Corresponding author.

E-mail address: syzheng@shmtu.edu.cn (S. Zheng).
} 
not provide comprehensive and general answers to the basic questions of "how to govern" and "govern for what" in port governance, because of the complex nature of the topic and controversial issues related to it. Our study treats itself as an initial effort to manifest the basic components of port governance by putting forward the answers to the two mentioned unanswered questions according to the overview of port governance in the international arena. Because of the increasing common characteristics of the port governance reform process around the globe (Brooks et al., 2017; Zhang et al., 2018), we believe this study, to a great extent, can improve the understanding of port governance and help policy and decision makers to address the port governance issues more effectively.

This paper is organized as follows. In Section 2, the applied methodological procedures and collection of reviewed studies are briefly presented. Also, we discuss in this section the bibliometric analysis of the selected literature sample. In Section 3, we present answers to the questions of "how to govern" and "govern for what". Section 4 concludes.

\section{Literature sample collection and descriptive analysis}

The initial sample is composed of 77 reviewed studies selected by Zhang et al. (2018), in which a five-step approach (i.e. Step 1: eligibility criteria; Step 2: preliminary selection; Step 3: further selection; Step 4: semi-final selection; Step 5: representativeness and final selection) is developed and applied (see details in Zhang et al., 2018).

The authors further enlarge the original literature sample from the existing port governance researches by adding additional sample studies. With regard to the additional studies, a similar literature selection approach is adopted. More specifically, the following objective eligibility criteria are set down according to the research topic: (i) Field of studies: the studies should deal with seaport management; (ii) Topic of "port governance": the studies should contain characters "port(s)", "governance", "tool(s)" and/or "purpose(s)" in the title and/or abstract and/or keywords; (iii) Language of studies: the studies should be published in English; (iv) Publication status: only studies published in academic journals and chapters in books are reviewed; (v) Year of publication: studies should be published before 1st July 2018 (the last day of searching literature). Web of Science and Science Direct are the two literature databases used for searching. The detailed literature selection is organized as follows.

(I) Preliminary selection. In the two mentioned databases, the terms "port governance tool" and "port governance purpose" are separately searched in title and/or abstract and/or keywords. The search results pertaining to "port governance tool" have 15 and 19 records respectively. The search results regarding "port governance purpose" have 11 and 20 records respectively. After excluding duplicated studies, there are 51 records left in total, among which, 7 studies are already included in the original literature sample in Zhang et al. (2018). Therefore, 44 records are left according to the preliminary selection.

(II) Record checking. Each remaining record is checked by scanning its title, abstract and keywords to see whether it satisfies the criteria. A full reading of a recorded study has to be conducted when it is necessary. Three of the authors have independently participated in this selection process and formed their own lists of recorded studies focusing on the research topic. The fourth author acts as a coordinator to compare the lists and organize a collective telephone meeting to discuss the differences. As a result, 29 of 44 records are identified as the non-related studies and excluded finally. These studies focus on other topics such as airport governance, port-city interaction governance. At last, 15 remaining records are picked up as the eligible studies that can be included in the literature sample.

(III) Literature supplement. All of our authors think that 15 additional studies are not sufficient and there exists a need to further enlarge the sample. Then the authors conduct a collective discussion to determine the other additional studies that should be included in our final literature sample. In this process, the perspectives derived from the previously collected literature and the authors' own expert insights play an important role. Specifically, since the concession agreement is clearly listed as a port governance tool by Notteboom (2006) and Panayides et al. (2017), we decide to include seven papers from the special issue (Volume 39, 2012) of Maritime Policy \& Management (MPM) on terminal concessions in seaports, aiming at gaining more understanding of concessions. Moreover, port cooperation is explicitly considered as a governance tool by Knatz (2018). Driven by the fact that port industry has witnessed a multiplication of port cooperation and integration schemes in recent years (Notteboom et al., 2018), we think it is necessary to include papers from the special issue (Volume 26, 2018) of Research in Transportation Business \& Management (RTBM) on port co-operation/integration. Besides, several studies on port efficiency and/or effectiveness are also proposed and included, such as Pagano et al. (2013), Zheng and Yin (2015); Serebrisky et al. (2016) and Coto-Millán et al. (2016). Finally, 26 studies are added to the previous additional list of 15 studies, and these 41 studies constitute the final additional literature sample, which accompanies with the original literature sample of 77 studies in Zhang et al. (2018), jointly forming the final literature sample of 118 studies in present paper. It is worth mentioning that the 26 studies that are determined by authors' collective discussion do not definitely contain characters "port(s)", "governance", "tool(s)" and/or "purpose(s)" in the their titles and/or abstracts and/or keywords but they are closely related to the research topics discussed in this paper.

Fig. 1 shows an increase of studies on port governance from 2012 onwards. The year 2006 can be considered as an exception, because a

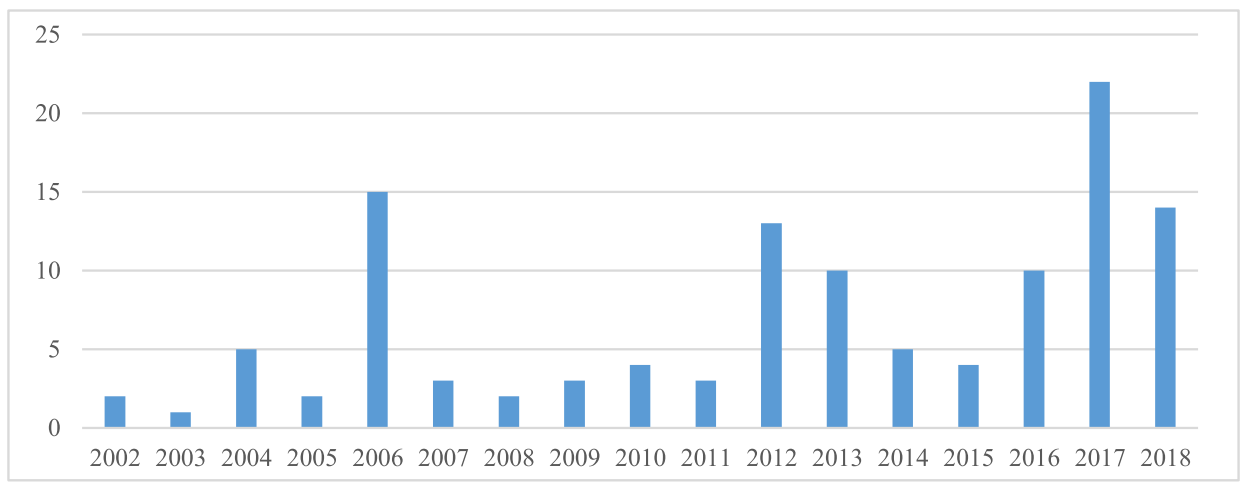

Fig. 1. The distribution of number of the reviewed studies by year. 
Table 1

The major journals of the selected studies.

\begin{tabular}{lll}
\hline Journal & No. of studies & $\%$ \\
\hline Research in Transportation Business and Management & 38 & 32.2 \\
Maritime Policy and Management & 25 & 21.2 \\
Research in Transportation Economics & 18 & 15.3 \\
Transport Reviews & 8 & 6.8 \\
Journal of Transport Geography & 6 & 5.1 \\
Transport Policy & 5 & 4.2 \\
International Journal of Transport Economics & 2 & 1.7 \\
International Journal of Shipping and Transport Logistics & 2 & 1.7 \\
Other journals (one article each) & 9 & 7.6 \\
Book chapter (chapters in different books) & 5 & 4.2 \\
Total & 118 & 100 \\
\end{tabular}

special issue on port governance themed "Devolution, Port Governance and Port Performance" was published in Research in Transportation Economics (RTE) in this year. The highest number of published studies on port governance took place in 2017, when the special issue of "Revisiting Port Governance and Port Reform" was published in RTBM.

Table 1 below shows the distribution of the reviewed studies by journal and number. Of the total 118 selected studies, more than twothirds are published in three major journals, namely Research in Transportation Business \& Management (RTBM), Maritime Policy \& Management (MPM) and Research in Transportation Economics (RTE), with nearly $32 \%$ (38 studies) in RTBM, 21\% (25 studies) in MPM, and 15\% (18 studies) in RTE, respectively. Compared with the literature sample collected in Zhang et al. (2018), half of additional reviewed studies included in the current sample are published in RTBM (15 studies are newly added) and MPM (16 studies are newly added). The eight journals listed in Table 1 dominate the research field of port governance studies, which is in line with the result concluded in Zhang et al. (2018).

Regarding the geographical analysis unit of the selected studies, the overall distribution (see Table 2) of the sample studies is similar to the sample distribution observed in Zhang et al. (2018), where the majority of studies (50\%) focus on the national level by taking national specific managerial and institutional characteristics into research consideration. In order to capture the homogeneity of port governance reforms, an increasing number of studies are conducted at the global scale (27.9\%)

Table 2

The geographical analysis unit of the selected studies.

\begin{tabular}{|c|c|c|}
\hline Unit of analysis & No. of studies & $\%$ \\
\hline $\begin{array}{l}\text { Global (samples across continents or theoretical work } \\
\text { without samples) }\end{array}$ & 33 & 27.9 \\
\hline $\begin{array}{l}\text { International region (samples across countries within } \\
\text { a continent) }\end{array}$ & 18 & 15.3 \\
\hline European Continent & 11 & \\
\hline American Continent & 5 & \\
\hline Asian Continent & 1 & \\
\hline African Continent & 1 & \\
\hline National (including samples within domestic regions) & 59 & 50.0 \\
\hline European country & 25 & \\
\hline Asian country & 18 & \\
\hline American country & 12 & \\
\hline Oceania country & 3 & \\
\hline African country & 1 & \\
\hline Specific port & 8 & 6.8 \\
\hline $\begin{array}{l}\text { European port (i.e. Port of Rotterdam, Antwerp, } \\
\text { Hamburg and Piraeus) }\end{array}$ & 5 & \\
\hline Asian port (i.e. Port of Hong Kong, and Busan) & 2 & \\
\hline American port (i.e. Port of New York-New Jersey) & 1 & \\
\hline Total & 118 & 100 \\
\hline
\end{tabular}

Table 3

The research methods adopted in the selected studies.

\begin{tabular}{lll}
\hline Method & No. of studies & $\%$ \\
\hline Survey & 11 & 9.3 \\
Interview & 3 & 2.5 \\
Economic modelling by applying economic theories & 12 & 10.2 \\
Pure mathematical modelling & 0 & 0 \\
Simulation & 0 & 0 \\
Case study & 58 & 49.2 \\
Conceptual works including conceptual modelling and & 23 & 19.5 \\
$\quad$ descriptive studies & & \\
Archival analysis & 1 & 0.8 \\
Content analysis & 10 & 8.5 \\
Total & 118 & 100 \\
\hline
\end{tabular}

and across countries within a continent (15.3\%). For instance, Brooks et al. (2017) study the commonalities of the port reform process in a multi-country geographical level. Van der Lugt et al. (2017) analyzes the strategic beliefs of port authorities using data from an international survey, while Farrell (2012) conducts a study on the ownership and management structure of container terminal concessions worldwide. Only a small number of studies (6.8\%) take specific ports within a country as geographical analysis unit.

With regard to the applied methodology in the sampled literature, the methods identified in the review study by Woo et al. (2011) are used to categorize our reviewed studies (see Table 3). It is worthy to highlight that case study (49.2\%) is the most common method used in port governance research field, which greatly shows the potential existence of local embeddness of port governance. Moreover, conceptual frameworks (19.5\%) are increasingly built to better illustrate the issues of port governance. For example, a three-dimensional model developed by Wang et al. (2004) on Chinese port governance. In addition, economic modelling $(10.2 \%)$, survey $(9.3 \%)$, content analysis $(8.5 \%)$, interview (2.5\%) and Archival analysis (0.8\%) are also identified as research methods in our literature sample. Notably, the study by Knatz (2018) is the only study that conducts an archival analysis, which uses a lot of early historical records as empirical data to extract evidence. Content analysis as an emerging method in the port governance research domain has been applied by an increasing number of studies, such as Brooks (2017) and Notteboom et al. (2015). Pure mathematical modelling and simulation are not used in the selected studies, which considerably indicates that qualitative methods rather than quantitative methods are dominant in the field.

The analysis presented above shows that the body of research on port governance is entering a mature phase, with the growing number of studies on port governance and a clear concentration of relevant publications in a limit number of journals. Also, there is an increase in studies focusing on the commonalities of port governance issues around the globe, although the analysis of port governance at the national level is still important in the port research field. Generally, qualitative methods are more common to be utilized by port governance studies.

\section{The review of existing literature on port governance}

Before presenting the detailed outcomes of this review study on the two core research questions, we would like to elaborate how the studies gathered in the final literature sample are analyzed and interpreted. A methodology similar to "identification-judgement-confirmation" approach developed by Zhang et al. (2018) is adopted. More specifically, each study in the sample is fully read by two of the authors respectively. The two authors are separately given the same task to list the port governance tools and/or purposes that are explicitly or implicitly argued by each study according to their own interpretation. They are also asked to present the related contents from the reviewed studies to support their judgements. Notably, the two authors are not allowed to have any discussion on their records during this process. Once the two 
authors finish their lists, one of another two authors is tasked to compare the two lists of the port governance tools and purposes that derived from the sampled literature and figure out the differences between the lists. Subsequently, a telephone meeting is organized for all the four authors to collectively discuss the answers to the questions of "how to govern" and "govern for what". The structure of how to present these answers is also decided in this meeting. It is useful to highlight that the necessary literature filtering has been done in the following presentations, especially in Tables 4 and 6 below where port governance tools and purposes are particularly elaborated. The most important principle that we stick to, in the process of the filtering, is to manifest the typically related studies that can significantly convey the main perspectives.

\subsection{How to govern in port governance}

When we explore the question of "how to govern" in port governance, we are actually seeking the governance tools that are used by governing actors namely governmental organizations and port organizations. Frankly speaking, the range of port governance tools available to governing actors is extremely extensive and complicated. As to the extensiveness, pricing, monitoring and measuring, market access control and environmental standard regulation are all the typical governance tools (Lam and Notteboom, 2014). Note that beyond the mentioned ones, there are still numerous tools such as terminal concession (Notteboom et al., 2012), port co-operation/integration (Notteboom et al., 2018), ICTs (Cepolina and Ghiara, 2013). Regarding the complication, many widespread port governance tools have different types, roles or functions in different regions and/or countries. Taking the terminal concession as an example, the ownership and management structure significantly vary according to the institutional environment, market awareness, and market contestability (Farrell, 2012). However, it does not mean that governance tools could not be understood from a holistic perspective in a general sense. The study by Brooks and Pallis (2008) provides an inspiring and useful stepping stone for our study. According to Brooks and Pallis (2008), governance decisions and governance models can be considered as "inputs" in port governance, and these inputs are defined at two levels, namely government-level and firm-level. In order to more clearly present those governance tools/inputs, in the current study, we decide to articulate the governance tools at the institutional, strategical, and managerial level, respectively.

Specifically, at the institutional level, we focus on the tools that are related to the changes or adjustments of port governance configuration such as the reallocation of responsibilities, the decentralization of port administration. Therefore, the governance tools at institutional level are generally used by governmental organizations, one of the two main governing actors in port governance. For instance, port devolution (Brooks and Cullinane, 2006) is a typical tool in this category. At the strategical level, we concentrate on the tools adopted by port organizations, the other main governing actor, to gain a more favorable competitive market position in a relatively long term. These tools include port co-opetition (Song, 2003), port regionalization (Notteboom and Rodrigue, 2005), port integration (Notteboom and Yang, 2017), etc. At the managerial level, the tools relating to the port business operations and management are discussed. For example, terminal concession (Notteboom et al., 2012), ports' carbon footprint monitoring and measuring (Lam and Notteboom, 2014), real estate development and commercial negotiations with port customers (Verhoeven, 2010), etc. Through an intensive review of the studies in our literature sample, in Table 4 below, we present the main governance tools and their characteristics, general descriptions, types, and applied geographical scopes.

Regarding the governance tools presented, port devolution and port re-centralization are identified as two main governance tools at the institutional level. Unlike the widespread port devolution that dominates the first wave of port reforms in the 1990s (Brooks et al., 2017), port re-centralization has emerged in the past decade in some countries (e.g. Brazil, China, Italy) with increasing involvements by national or regional governments beyond local governments (Zhang et al., 2018). Note that as the governance tools at the institutional level, port devolution and port re-centralization substantially set the fundamental regulative rules for the port governance configuration and allocation of responsibilities between governing actors.

At the strategical level, port co-opetition, port regionalization, port integration, stakeholder management strategy, and corporate governance are listed as the main governance tools. Compared with the governance tools at the institutional level, the tools at the strategical level focus more on the internal and external relations of port organizations. In general, those strategical governance tools are extensively adopted by ports to develop a better relationship with port users, hinterlands, local communities, and even port rivals, etc. It should be especially mentioned here that port investment is an important sub-tool included in these strategical tools. For instance, the investment in inland terminals and the corridors connecting inland terminals and seaports is crucial in port regionalization (Notteboom and Rodrigue, 2005).

There are seven main tools are derived and presented at the managerial level, namely port pricing, port concession, port user/customer relationship management, monitoring and measuring, regulatory control, port security management, and information and communication technologies (ICTs). Unlike the tools at the institutional and strategical levels, the governance tools at the managerial level are more operational, universally observed, and closely related to the port business performance. It is worth noting that the regulatory control mentioned here is different from the fundamental regulative rules setting for the port governance configuration, it is managerial and operational in nature by establishing a stable framework to guide the port activities in a transparent, predictable, and accountable manner.

The fourteen governance tools at three different levels derived from the reviewed studies, to a great extent, construct the answer to the question of "how to govern". In practice, a port is generally governed by using these governance tools comprehensively. Note that most of the governance tools can be adopted simultaneously, while some tools, especially the tools related to the fundamental regulative rules setting at the institutional level, have totally different inherent governance orientation, therefore, they cannot be used at the same time. For instance, port devolution emphasizes the decentralization in the port administrative system, however, the port re-centralization advocates the greater involvement of upper governments in port management issues. Based on the elements of port governance tools summarized in Table 3 above, we can further clarify the question of "how to govern" from the view of port governance homogeneity and heterogeneity.

First of all, all governance tools at three mentioned levels can be specifically divided into several types from certain perspectives. For example, from the perspective of governance structure, port devolution can be divided into five types with different governance actors having different corresponding roles in port governance (Brooks and Cullinane, 2006). The diversity of port governance tools and their various types have largely shown the complexity of port governance (Debrie et al., 2013). Through the identification of the main types within each governance tool, we can get closer to the concrete contents and/or measures of "how to govern" in port governance.

Moreover, the majority of the presented governance tools are applied worldwide. However, port re-centralization at the institutional level is relatively absent from the international arena. Compared with port devolution, the other institutional governance tool that is generally considered as a part of a larger attempt by governments to apply New Public Management (NPM) concepts to the transportation sector (Baltazar and Brooks, 2006), there is still no consensus on the philosophy behind port re-centralization in the port governance system yet. Nevertheless, some existing studies, to a certain extent, reveal some reasons behind this governance change, including the upper governments' expectation of enhancing regional and/or national port 
Table 4

The main governance tools identified at institutional, strategical, and managerial levels.

\begin{tabular}{|c|c|c|c|c|c|}
\hline Analytical level & Governance tool & Main characteristics & The general description and the main types & The geographical scope that is adopted & Main References \\
\hline $\begin{array}{l}\text { At the } \\
\text { institu- } \\
\text { tional level }\end{array}$ & Port devolution & $\begin{array}{l}\text { (1) Changed government } \\
\text { objectives; } \\
\text { (2) Changed organizational } \\
\text { structure; } \\
\text { (3) Changed governing actors in } \\
\text { port operations and } \\
\text { management. }\end{array}$ & $\begin{array}{l}\text { General description: A part of a larger } \\
\text { attempt by governments to apply New } \\
\text { Public Management (NPM) concepts to the } \\
\text { port sector. Governments devolve ports by } \\
\text { transferring the port authorities functions to } \\
\text { a lower level government or to a new entity. } \\
\text { Main types (reform perspective): (1) }\end{array}$ & Worldwide & $\begin{array}{l}\text { Debrie et al. } \\
\text { (2007); Brooks } \\
\text { and Cullinane } \\
\text { (2006); Baltazar } \\
\text { and Brooks } \\
\text { (2006) }\end{array}$ \\
\hline
\end{tabular}

Decentralization; (2) Commercialization

(3) Corporatization; (4) Privatization.

Main types (structure perspective): (1)

Central government owned with central

government management and control; (2)

Government owned but management and

control are decentralized to a

local government body; (3) Government

owned (federal, regional or municipal) but managed and controlled by a corporatized entity; (4) Government owned but managed by a private sector entity, or owned and managed by a public-private partnership; (5) Fully privately owned, managed and controlled.

\section{At the Port co- \\ strategical opetition level}

Port re-

centralization

(1) Greater involvement by upper governments;

(2) Decisional power shifted from the periphery to the core;

(3) The centralized port administration.
General description: Unlike port devolution, the upper governments centralize the port administration through the legislation or government decrees. Main types: (1) The existing regulatory agencies gain more power (e.g. Ports Secretariat (SEP) and Brazilian Waterways Regulatory Agency (ANTAQ) in Brazil); (2) A new governmental organization at upper level is set up (e.g. Zhejiang Seaport Development Committee (ZSDC) in China); (3) Regional port authorities replace traditional local port authorities (e.g. 24 local port authorities are replaced by 15 port system authorities in Italy); (4) The governmental organizations increase their engagement by providing more funding for ports (e.g. in 2009, the U.S. Department of Transportation (DOT) established a federal funding program, which allows ports to apply for funds).

(1) A mixture of competition and General description: The combination of cooperation;

(2) A way of collaborating to compete

(3) To a certain extent, coopetitive relationship is difficult to maintain over the long term.

Port regionalization

(1) A gradual and market-driven process;

(2) As a result of logistics integration and network orientation in the port and maritime industry;

(3) Changing the geographical scope of port governance.

Port integration (1) Generally happen between/ among ports in proximity;

(2) In pursuit of larger market shares, the increase of port capacity, the optimization of port cooperation and competition.

Main types: (1) Port cooperation (e.g.

merge and consolidation; port alliance; joint venture/network/platform; joint research and development; bundling/redistribution of cargo flows); (2) Port competition (e.g. win/lose proposition with rivals; direct competition within a shared hinterland). General description: Port regionalization represents an evolutionary stage in port development, where efficiency is derived with high levels of integration of inland freight distribution centers/intermediate hubs.

Main types: (1) Hinterland-based regionalization (i.e. the formation of a regional load center network in the hinterland); (2) Foreland-based regionalization (i.e. the integration of intermediate hubs in regional shipping networks); (3) Regionalization with specialization (i.e. developing specializations with links to different markets).

General description: Strictly speaking, port integration is one of the forms of port cooperation. However, compared with other forms of cooperation, integration means the closest partnership between cooperative parties. It usually manifests itself through
Still seldom observed in the Huo et al. international arena at present (Note: In (2018); Galvão general, port centralization happens in et al. (2017); a country with fierce inter-port Notteboom and competition and a relatively powerful Yang (2017); central/federal and/or provincial/ Parola et al. regional upper government) (2017); Knatz (2017) $\begin{array}{ll}\text { Worldwide } & \text { Brooks et al. } \\ & \text { (2017); } \\ & \text { Mclaughlin and } \\ & \text { Fearon (2013); } \\ & \text { Van Donselaar } \\ & \text { and Kolkman } \\ & (2010) ; \text { Song } \\ & (2003)\end{array}$

Worldwide (Note: Foreland-based regionalization is especially $i$ for intermediate hubs with significant Notteboom transshipment traffic)

(2010);

Notteboom and Rodrigue (2005)
Worldwide (Note: Especially for those ports in proximity, who are facing the problems of overcapacity, underutilization of port resources, conflicting port planning, etc.)
Shinohara and Saika (2018); Wu and Yang (2018); Notteboom and Yang (2017); 
Table 4 (continued)

\begin{tabular}{|c|c|c|c|c|c|}
\hline Analytical level & Governance tool & Main characteristics & The general description and the main types & The geographical scope that is adopted & Main References \\
\hline & & $\begin{array}{l}\text { port resources utilization, } \\
\text { holistic port planning, etc. } \\
\text { (3) Usually need the support and/ } \\
\text { or engagement of port } \\
\text { administrations. }\end{array}$ & $\begin{array}{l}\text { mergers and acquisitions. } \\
\text { Main types (driven force perspective): } \\
\text { (1) Government-driven mode; (2) Market- } \\
\text { driven mode; (3) Government/market- } \\
\text { driven mode; (4) Strategic alliances driven } \\
\text { by multi-factor. } \\
\text { Main types (spatial coverage } \\
\text { perspective): (1) Port internal integration; } \\
\text { (2) Jurisdictional port integration; (3) } \\
\text { Integration across neighbor region; (4) } \\
\text { Regional port integration; (5) Hub-feeder } \\
\text { port integration. }\end{array}$ & & $\begin{array}{l}\text { Wang et al. } \\
\text { (2015) }\end{array}$ \\
\hline & $\begin{array}{l}\text { Stakeholder } \\
\text { management } \\
\text { strategy }\end{array}$ & $\begin{array}{l}\text { (1) There are a multitude of } \\
\text { stakeholders; } \\
\text { (2) Stakeholder satisfaction is an } \\
\text { important measure of the } \\
\text { success of a change in port } \\
\text { governance; } \\
\text { (3) Stakeholders' expectations can } \\
\text { vary substantially when taking } \\
\text { into account spatial } \\
\text { dimensions. }\end{array}$ & $\begin{array}{l}\text { General description: Stakeholder } \\
\text { management strategy focuses on balancing } \\
\text { the diversified interests of the groups or } \\
\text { organizations that have interests or } \\
\text { concerns in port governance issues. } \\
\text { Main types (actors perspective): (1) Port } \\
\text { users; (2) Local communities; (3) Interest } \\
\text { groups; (4) Government agencies; (5) Other } \\
\text { relevant stakeholders. } \\
\text { Main types (spatial and temporal } \\
\text { perspective): (1) Location independent } \\
\text { changes in stakeholder structure and } \\
\text { interests; (2) Location dependent changes in } \\
\text { stakeholder structure and interests. }\end{array}$ & $\begin{array}{l}\text { Worldwide (Note: Especially in a } \\
\text { country where there exist relatively } \\
\text { democratic political system and } \\
\text { environment) }\end{array}$ & $\begin{array}{l}\text { Yoshitani } \\
\text { (2018); Lam et } \\
\text { al. (2013); } \\
\text { Ghashat and } \\
\text { Cullinane } \\
\text { (2013); Dooms } \\
\text { et al. (2013) }\end{array}$ \\
\hline & $\begin{array}{l}\text { Corporate } \\
\text { governance }\end{array}$ & $\begin{array}{l}\text { (1) Port governance includes the } \\
\text { corporate governance at the } \\
\text { internal firm level; } \\
\text { (2) There are many variations of } \\
\text { corporate governance in port } \\
\text { governance; } \\
\text { (3) In port field, broader social } \\
\text { responsibilities may be } \\
\text { incorporated into the port } \\
\text { organizations' vision. }\end{array}$ & $\begin{array}{l}\text { General description: The traditional } \\
\text { corporate governance is the structure, roles, } \\
\text { and responsibilities that provide the means } \\
\text { by which the organization is managed as an } \\
\text { economic entity basing on the objectives of } \\
\text { the corporation in the interests of its } \\
\text { shareholders or members. } \\
\text { Main types (component perspective): (1) } \\
\text { Objectives and mission statement; (2) } \\
\text { Competences and composition of } \\
\text { supervisory boards; (3) Use of public } \\
\text { selection procedures to contract land out; } \\
\text { (4) Existence of corporate social } \\
\text { responsibility (CSR) policy; (5) Accounting } \\
\text { practices. } \\
\text { Main types (theory perspective): (1) } \\
\text { strategic management; (2) organization } \\
\text { theory; (3) configuration theory. }\end{array}$ & $\begin{array}{l}\text { Worldwide (Note: Especially in a } \\
\text { country where port organizations are } \\
\text { publicly traded companies, and } \\
\text { principles are established for the good } \\
\text { and transparent corporate governance) }\end{array}$ & $\begin{array}{l}\text { Brooks (2016); } \\
\text { Verhoeven and } \\
\text { Vanoutrive } \\
\text { (2012); Brooks } \\
\text { and Pallis } \\
\text { (2012); Baltazar } \\
\text { and Brooks } \\
\text { (2006); Brooks } \\
\text { (2004) }\end{array}$ \\
\hline \multirow[t]{2}{*}{$\begin{array}{l}\text { At the } \\
\text { managerial } \\
\text { level }\end{array}$} & Port pricing & $\begin{array}{l}\text { (1) It is an important means for } \\
\text { ports to gain incomes; } \\
\text { (2) It varies across countries and } \\
\text { regions; } \\
\text { (3) Pricing control, such as } \\
\text { incentive and penalty pricing, } \\
\text { is universally used in port } \\
\text { industry. } \\
\text { (4) Influenced by the cost, market } \\
\text { structure, demand and } \\
\text { institutional factors, etc. }\end{array}$ & $\begin{array}{l}\text { General description: Port pricing mainly } \\
\text { includes the design of port tariff structure } \\
\text { and port service charges. } \\
\text { Main types (tariff perspective): (1) } \\
\text { Infrastructure tariffs (e.g. channel and berth } \\
\text { charges); (2) Non-infrastructure tariffs (e.g. } \\
\text { cargo handling charges). } \\
\text { Main types (pricing strategy } \\
\text { perspective): (1) Economic approach; (2) } \\
\text { Financial approach; (3) Public enterprise } \\
\text { approach. } \\
\text { Main types (doctrine perspective): (1) } \\
\text { Anglo-Saxon doctrine (e.g. full cost recovery } \\
\text { pricing; no-subsidy); (2) European doctrine } \\
\text { (e.g. marginal port pricing; subsidies); (3) } \\
\text { Asian doctrine (e.g. administered pricing; } \\
\text { cross-subsidization; public enterprise } \\
\text { approach). }\end{array}$ & Worldwide & $\begin{array}{l}\text { Lam and } \\
\text { Notteboom } \\
\text { (2014); Bandara } \\
\text { et al. (2013); } \\
\text { Lee and Flynn } \\
\text { (2011) }\end{array}$ \\
\hline & Port concession & $\begin{array}{l}\text { (1) Basic port infrastructure } \\
\text { remains in public ownership, } \\
\text { while terminal operations are } \\
\text { controlled by a separate entity } \\
\text { which is at least partly owned } \\
\text { by private companies; } \\
\text { (2) Competitive bidding is the } \\
\text { most common procedure used } \\
\text { in concession granting; } \\
\text { (3) It appears to be the only } \\
\text { appropriate and common } \\
\text { instrument to influence the } \\
\text { achievement of the port }\end{array}$ & $\begin{array}{l}\text { General description: A concession is a } \\
\text { grant by a government or port authority to a } \\
\text { (private) operator for providing port } \\
\text { services (normally cargo handling) within a } \\
\text { limited period of time. The optimal } \\
\text { concession contracts are determined by port } \\
\text { authorities' goals to a great extent. } \\
\text { Main types (form perspective): (1) Long- } \\
\text { term leases; (2) Operating licenses; (3) } \\
\text { Build-Operate-Transfer (BOT) schemes. } \\
\text { Main types (partner perspective): (1) } \\
\text { Competitively tendered; (2) Negotiated }\end{array}$ & $\begin{array}{l}\text { Worldwide (Note: A large diversity } \\
\text { exists among ports all over the world, } \\
\text { particularly in terms of the type of } \\
\text { award arrangement and the specificity } \\
\text { of the awarding procedures deployed) }\end{array}$ & $\begin{array}{l}\text { Ferrari et al. } \\
\text { (2015); Chen } \\
\text { and Liu (2015); } \\
\text { Notteboom et al. } \\
\text { (2012); Farrell } \\
\text { (2012); } \\
\text { Notteboom } \\
\text { (2006) }\end{array}$ \\
\hline
\end{tabular}


Table 4 (continued)

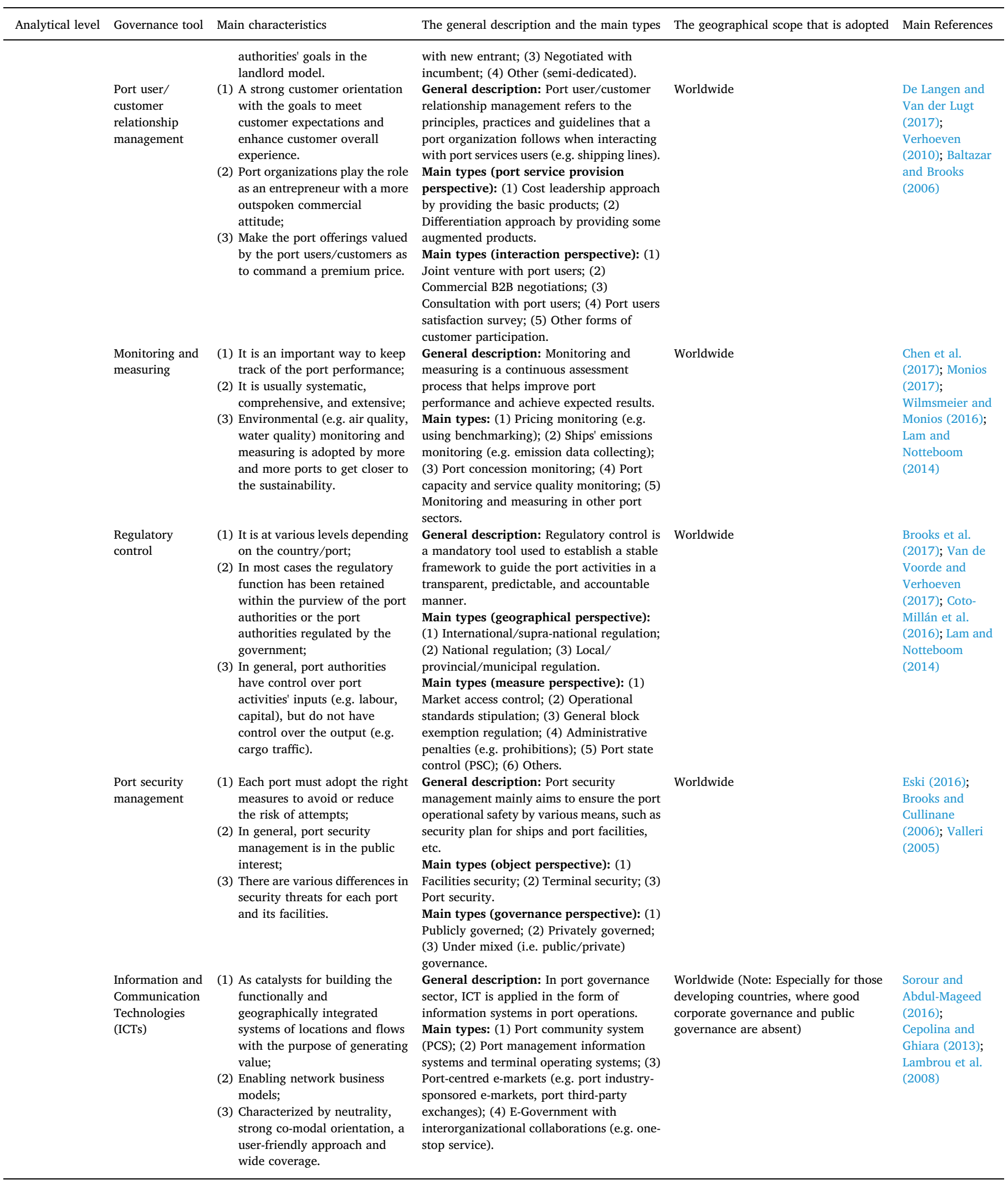


Table 5

Alternative configuration in the matching framework based on configuration theory.

\begin{tabular}{|c|c|c|}
\hline & Efficiency-oriented configuration & Effectiveness-oriented configuration \\
\hline Environment & Low uncertainty (Low complexity and dynamism) & High uncertainty (High complexity and dynamism) \\
\hline Strategy & $\begin{array}{l}\text { Narrow product market scope; Cost leadership approach (Focus on delivery of } \\
\text { the basic product or service) }\end{array}$ & $\begin{array}{l}\text { Broad product market scope; Differentiation approach (Focus on delivery of } \\
\text { augmented products and services) }\end{array}$ \\
\hline Structure & $\begin{array}{l}\text { Mechanistic (Centralized decision-making characterized by higher } \\
\text { standardization and lower customization) }\end{array}$ & $\begin{array}{l}\text { Organic (Decentralized decision-making characterized by higher customization } \\
\text { and lower standardization) }\end{array}$ \\
\hline
\end{tabular}

Source: Baltazar and Brooks (2006).

Table 6

The main objectives of port governance: efficiency and effectiveness.

\begin{tabular}{|c|c|c|c|}
\hline Governance objective & Main characteristics & The general description and the main types & Main References \\
\hline Port efficiency & $\begin{array}{l}\text { (1) There are different measures of } \\
\text { efficiency; } \\
\text { (2) Efficiency is a relative concept that } \\
\text { requires a clearly defined benchmark } \\
\text { in order for the comparison between } \\
\text { ports; } \\
\text { (3) There exist regulatory effects on port } \\
\text { efficiency (i.e. port governance reforms } \\
\text { have impacts on port efficiency). }\end{array}$ & $\begin{array}{l}\text { General description: Port efficiency is concerned } \\
\text { with measuring the extent to which a port is able to } \\
\text { produce a maximum level of output given a set of } \\
\text { inputs, and combine these inputs in an optimal way. } \\
\text { Main types (efficiency component perspective): } \\
\text { (1) Technical efficiency; (2) Allocative efficiency; (3) } \\
\text { Economic efficiency; (4) Cost efficiency. } \\
\text { Main types (operational indicator perspective): (1) } \\
\text { Moves per ship-hour; (2) Moves per crane-hour; (3) } \\
\text { Ship delay; (4) Ship dwell time; (5) Ship productivity, } \\
\text { etc. } \\
\text { Main types (method of efficiency measurement } \\
\text { perspective): (1) Data envelopment analysis (DEA); } \\
\text { (2) Stochastic frontier analysis (SFA). }\end{array}$ & $\begin{array}{l}\text { Caldeirinha et al. (2018); Merkel and Holmgren } \\
\text { (2017); Serebrisky et al. (2016); Coto-Millán et al. } \\
\text { (2016); Pagano et al. (2013); Brooks and Pallis } \\
\text { (2008); Talley (2006); Cullinane and Song (2002) }\end{array}$ \\
\hline Port effectiveness & $\begin{array}{l}\text { (1) Effectiveness-oriented port } \\
\text { performance is related to the quality of } \\
\text { services provided to port users; } \\
\text { (2) Effectiveness is measured relative to } \\
\text { the objectives being sought in port } \\
\text { governance; } \\
\text { (3) Port governance model mechanisms } \\
\text { influence port effectiveness. }\end{array}$ & $\begin{array}{l}\text { General description: Port effectiveness is always } \\
\text { measured in terms of what the port users of the port } \\
\text { services expect by way of port performance. } \\
\text { Main types (operating objective perspective): (1) } \\
\text { Maximize profits/throughput subject to a minimum } \\
\text { profit constraint (for a privately-owned port); (2) } \\
\text { Maximize throughput subject to a zero/maximum } \\
\text { operating deficit (for a government-owned port). } \\
\text { Main types (practical initiatives for port user } \\
\text { assessment perspective): (1) Container Terminal } \\
\text { Quality Indicator (developed by Germanischer Lloyd } \\
\text { in 2008); (2) Port Performance Indicators: Selection } \\
\text { and Measurement (developed by European Sea Ports } \\
\text { Organization in 2012); (3) An assessment of } \\
\text { individual container ports on user-specific service } \\
\text { criteria (adopted by American Association of Port } \\
\text { Authorities in 2012). }\end{array}$ & $\begin{array}{l}\text { Caldeirinha et al. (2018); Brooks and Schellinck } \\
\text { (2015); Brooks et al. (2011); Brooks and Pallis } \\
\text { (2008); Talley (2006) }\end{array}$ \\
\hline
\end{tabular}

competitiveness (Parola et al., 2017; Knatz, 2017), the upper governments' efforts to improve port capacity coordination in a lower growth environment (Notteboom and Yang, 2017), the governments' pursuit of a more effective port management system (Galvão et al., 2017).

Finally, based on the characteristics and general descriptions of port governance tools, it is not hard to tell the close relationship between the governing actors and governance tools. As discussed before that "how to govern" is actually related to the governance tools that are used by main governing actors namely governmental organizations and port organizations. Because of the organizational nature, governmental organizations generally use institutional, juridical, regulatory tools, such as port devolution, port re-centralizations. While port organizations usually adopt commercial, contractual, operational tools, such as port co-opetition, port pricing, port concession, etc. It is worth noting that for some governance tools, they may include the efforts from both governmental organizations and port organizations. For example, port integration in China is a typical hybrid driven by governments and port enterprises (Wang et al., 2015).

\subsection{Govern for what in port governance}

The question of "govern for what" is closely interconnected to the question of "how to govern". Each governance tool used in port governance serve specific purposes or goals. The existing literature gives various answers to the question of "govern for what". For instance, Baltazar and Brooks (2006) argue that the main objectives of port devolution are improving efficiency, responsiveness, and port market competition. Song (2003) articulates that port co-opetition aims to achieve rationalization, cost saving, scale advantage, the benefit from risk sharing, the improving capacity utilization, and the increasing welfare of the economy, etc. Notteboom and Rodrigue (2005) propose that port regionalization has the goals of improving seaports' inland accessibility and mitigating local constraints (e.g. the lack of available land for port expansion, diseconomies caused by increased port traffic, local opposition to port development). Lambrou et al. (2008) stress the importance of ICT application in providing various benefits to the ports, such as quicker access to information, improved communication with customers and business partners, better customer service, reduced operational and administrative costs, higher productivity and quality of service. However, a closer look at the objectives of governance tools reveal some answers to the question of "govern for what" in port governance. It has been argued that in section 3.2 that the study on "how to govern" is strongly related to the identification of port governance tools/inputs used by governing actors, while the study on "govern for what" is more related to the output side of port governance, more specifically to the components of port performance. In line with Brooks 
and Pallis (2008), who stress the importance of efficiency and effectiveness as the two main components of port governance, the efficiency and effectiveness of port performance provide the answers to the question of "govern for what" in port governance.

It is worthy to mention that many ports around the world list economic development as one of their primary objectives aiming at creating jobs and opportunities for business instead of maximizing port efficiency or effectiveness in serving customers (Baltazar and Brooks, 2006). However, it is very difficult for ports to achieve long-term economic development without considering a significant improvement of port efficiency and effectiveness. Also, it is important to mention that "who governs" and "what is governed" largely determine "govern for what", because each governing actor has its own roles, functions and goals, and each governed object has its own scopes or boundaries (Zhang et al., 2018). Fig. 2 below illustrates the relationships between the four basic questions of port governance, namely who governs, what is governed, how to govern and govern for what. Before presenting more discussions on the efficiency and effectiveness, the paper will give more explanations to Fig. 2.

The relationship between "who governs" and "what is governed" is about "how to govern" in port governance (Zhang et al., 2018). Zhang et al. (2018) further elaborate four situations (i.e. governmental organizations directly control fundamentally regulative rules; governmental organizations directly control the specific port activities; port organizations directly control the specific port activities; governmental organizations directly or indirectly influence port organizations) where port governance tools are adopted and used. The governance tools listed in Table 3 all can be linked to the mentioned four situations. For instance, port devolution, a governance tool at the institutional level, shapes the relationship between governmental organizations and port organizations, and the degree of involvements of governmental organizations in port activities. Port co-opetition, a governance tool at the strategical level, relates to the various arrangements that port organizations adopt to compete and cooperate with each other in port activities. Port pricing, a governance tool at the managerial level, is about how port organizations charge their port users for port services. Therefore, the four situations are labeled as "how to govern" in Fig. 2.

Similarly, as in the case of "who governs" and "what is governed", the relationship between "how to govern" and "govern for what" is also interdependent. The question of "how to govern" is about actions, while "govern for what" is about objectives. In general, every action has its objectives, and the objectives also influence the action. Moreover, every objective is associated with actions, and the objective needs to be achieved by the actions.

As discussed before, port efficiency and effectiveness are the essential objectives of port governance tools. With the exception of the interdependence between "how to govern" and "govern for what", the "who governs" and "what is governed" also have strong influences on "govern for what". For example, a central goal of private sector involvement in port governance is stimulating efficiency (Pagano et al., 2013). The commercial nature of port development requires a governance structure focused on effective commercial operations (De Langen and Van der Lugt, 2017). Government will act as a regulator to secure the objects which are deemed to be in the public interest, such as public safety and security and the prevention of maritime pollution (Brooks and Cullinane, 2006). In the rest of this section, we focus on the further discussion on the efficiency and effectiveness under the umbrella of "govern for what" in port governance.

Regarding the efficiency, it relates to the physical quantities of items, levels of effort expanded, scale or scope of activities, and the efficiency in converting resources into some kind of product or service (Brooks and Pallis, 2008). While the effectiveness is concerned with how well the firm or agency uses its strategies, structure, and task environment to meet its mission and stated goals (Brooks and Pallis, 2008). More straightforward, efficiency is noted as "doing things right" while effectiveness is "doing the right things", the right things are those that are valued by the target customers or users (Brooks et al., 2011; Brooks and Schellinck, 2015). According to the matching framework proposed by Baltazar and Brooks (2006), port performance is a function of the match among the characteristics of the organization's external operating environment, strategies and structures. They further put forward two generic configurations in the matching framework, namely efficiency-oriented and effectiveness-oriented configurations. Each configuration is characterized by different operating environment, strategies and structures (see Table 5). Note that the choice of configuration in port governance is a matter of focus or emphasis on efficiency or effectiveness, but not the elimination of the other (Baltazar and Brooks, 2006).

As mentioned before, efficiency differs from effectiveness. However, efficiency and effectiveness are interactive concepts that are closely related to each other. In some cases, measures that are taken to improve port efficiency may also improve port effectiveness. While in some cases, port efficiency has been achieved at the expense of effectiveness (Brooks and Pallis, 2008).

More generally, in order for a port to be effective, it must be efficient (Talley, 2006). In terms of the general evaluation criteria on perceptions of port performance, according to an on-line survey completed by port users from three groups, namely carriers, cargo interests, and suppliers of services at the port, Brooks et al. (2011) present general determinants of satisfaction, competitiveness, and effectiveness of service delivery in port domain, which shows that competitiveness, as a proxy for efficiency, has the same determinants as satisfaction and effectiveness of service delivery. Those general determinants/criteria include fulfillment of special requests, overall reliability of the port, overall reputation of port, overall quality of cargo handling, port security, provision of adequate information, provision of on-time update of information, provision of accurate information, port safety, connectivity to rail/truck/warehousing companies, incidence of cargo damage, availability of direct service to the cargo's destination. Brooks and Schellinck (2015) further identify 13 main criteria that measure the effectiveness of the port's customer service delivery from the perspective of cargo interests. Some of these criteria are in line with the criteria presented by Brooks et al. (2011). Specifically, these 13 criteria reflect the overall reliability of the port, overall cost of using the port, provision of adequate on-time information, cost of rail/truck/warehousing, capability of employees, availability of direct service to the cargo's destination, terminal operator responsiveness to special requests, port authority responsiveness to special requests, incidence of cargo damage, port security, connectivity to rail/truck/warehousing, choice of rail/truck/warehousing companies, ability to develop/offer tailored services to different cargo interests.

To better understand port efficiency and effectiveness, Table 6 below illustrates the main characteristics, general descriptions, and main types of port efficiency and effectiveness based on the review of studies in our literature sample. In general, among the relevant port studies, most studies focus on port efficiency, only few studies examine port effectiveness (Pagano et al., 2013).

Based on Table 6, we can elaborate more discussions on port efficiency and effectiveness from two specific aspects.

First, regarding the methodology of measuring port efficiency and effectiveness, most researches on port efficiency are focusing solely on estimating technical efficiency by adopting DEA and/or SFA approach. A possible reason why only technical efficiency attracts most researchers' interest is the general difficulty in obtaining data concerning the relative prices of inputs and outputs that are required to form the iso-cost or iso-revenue curves (Merkel and Holmgren, 2017). The work of Merkel and Holmgren (2017) also points out that DEA and SFA methods produce the same metric of technical efficiency, and the estimates do not differ in theoretical interpretation. Compared to port efficiency studies, existing studies on port effectiveness generally adopt questionnaires of port users to examine effectiveness (Pagano et al., 2013; Ha et al., 2017). There still lacks studies on a systematic approach 


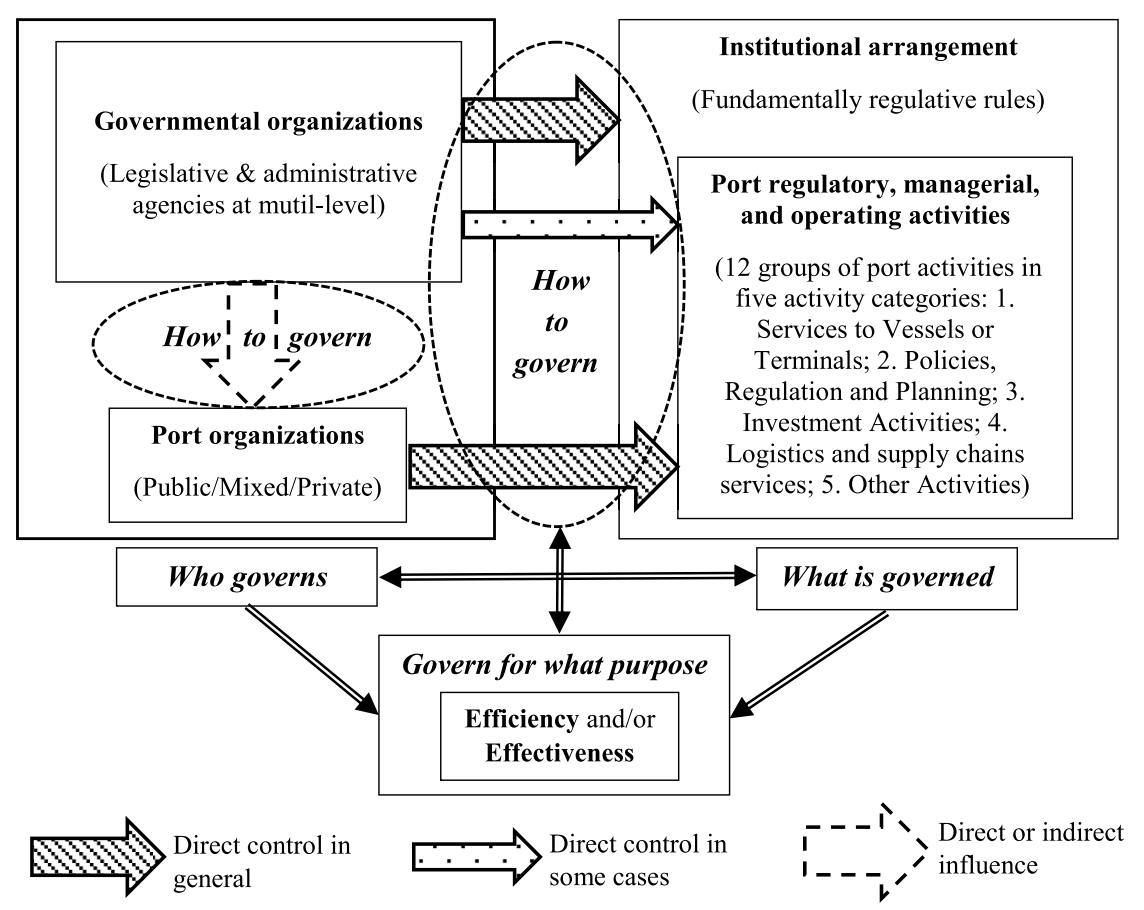

Fig. 2. The relationships between the four basic questions of port governance. Source: Authors own elaboration based on Zhang et al. (2018).

to comprehensively measure port efficiency and effectiveness. The work of Ha et al. (2017) can be considered as a great exploratory effort in the field, in their work, a integrated port performance measurement framework and a hybrid approach of fuzzy evidential reasoning (FER) with decision making trial and evaluation laboratory (DEMATEL) tool and analytical network process (ANP) are proposed.

Second, with regard to the port governance reforms' impacts on port efficiency and effectiveness, many studies (e.g. Cullinane and Song, 2002; Pagano et al., 2013; Coto-Millán et al., 2016; Serebrisky et al., 2016) show that port governance reforms focusing on the port devolution or port privatization generally have a positive impact on port efficiency. However, the results concerning port effectiveness are not definitive, which still needs more investigations (Pagano et al., 2013). Even so, some existing port governance studies (e.g. Castillo-Manzano et al., 2016; Caldeirinha et al., 2017; Caldeirinha et al., 2018) still, to a certain extent, reveal the positive relationship between port governance reforms and port effectiveness improvement. Note that more studies are needed to investigate the actual and/or potential impacts of recent port re-centralization and port integration on port efficiency and effectiveness, which is an emerging research gap in the field.

\section{Conclusions}

This study reviews a large number of relevant studies on port governance and tries to give answers to the two basic questions of port governance (i.e. how to govern and govern for what). The other two basic questions of port governance (i.e. who governs and what is governed) are discussed in Zhang et al. (2018). Therefore, the two studies are complementary and together offer a complete response to the four basic questions put forward by Vieira et al. (2014).

The sample of reviewed studies in this paper is composed of 118 studies that are collected from existing literature, among which 77 studies are the reviewed studies selected by Zhang et al. (2018), and 41 studies are newly added in the enlarged list.

As what is admitted by Zhang et al. (2018) that it is very hard to present universally satisfying answers to the basic questions of port governance, however, we believe that a better understanding of port governance, such us the specific manifestations of governing actors, governed objects, governance tools, and governance objectives, and the interrelationships between the basic components of port governance as illustrated in Fig. 2 can bring us closer to the inherent answers of these questions.

Regarding the question of "how to govern", this study identifies two main governance tools at the institutional level (i.e. port devolution and port re-centralization), five tools at the strategical level (i.e. port coopetition, port regionalization, port integration, stakeholder management strategy, and corporate governance), and seven tools at the managerial level (i.e. port pricing, port concession, port user/customer relationship management, monitoring and measuring, regulatory control, port security management, and ICTs) based on our reviewed studies. We also present these governance tools' main characteristics, general descriptions, types, and applied geographical scopes (see Table 3). The results show that except port re-centralization at institutional level is still seldom observed in the international arena at present, the other listed governance tools are almost worldwide observed, which, to a certain extent, means more academic attention need to be paid to port re-centralization as an emerging reform. According to the analysis of the mentioned fourteen governance tools, several policy implications can be further offered.

First, port devolution and port re-centralization, as the governance tools at the institutional level, substantially set the different fundamental regulative rules for the port governance system, the port administration at the central/federal government level needs to take the tools' characteristics, types, potential impacts into full consideration before the final decision making.

Second, as the tools at the strategical level generally focus on the internal and external relations of a port with port users, hinterlands, local communities, and even port rivals, port organizations need to form their suitable strategical governance tools configuration based on their own development situations, in order to achieve a more favorable competitive market position in a relatively long term.

Third, for the governance tools at managerial level are very various and closely related to the port daily business operations and management, it is important for port organizations, especially those port 
authorities, to continually promote their managerial governance tools to make sure the establishment of a stable framework to guide the port activities in a transparent, predictable, and accountable manner.

Concerning the question of "govern for what" in port governance, this study clearly points to the fact that port efficiency and effectiveness are exactly the main objectives of port governance. Efficiency is noted as "doing things right" while effectiveness is "doing the right things", they jointly constitute the components/outputs of port performance. The choice of efficiency-oriented or effectiveness-oriented configuration in port governance is largely determined by the port organization's external operating environment, strategies and structures. Our analysis also shows that a systematic approach is needed to comprehensively measure port efficiency and effectiveness by using qualitative and quantitative indicators, and more studies are needed to investigate the actual and/or potential impacts of recent port re-centralization and port integration on port efficiency and effectiveness concerning the policy implications, the analysis can imply that it is necessary for a port to establish its port efficiency and effectiveness measurement system, once the system is built, the port will more easily understand its governance performance and propose well-targeted measures to improve port performance.

In terms of the interrelationships between "who governs", "what is governed", "how to govern" and "govern for what" in port governance, it is critical to recognize that the relationship between "how to govern" and "govern for what" follows the same pattern of the relationship between "who governs" and "what is governed", more specifically, they both are interdependent. Moreover, "how to govern" connects "who governs" and "what is governed", meanwhile "who governs" and "what is governed" can also largely determine "govern for what", because each governing actor has its own roles, functions and goals, and each governed object has its own scopes or boundaries.

This paper, accompanying with the work of Zhang et al. (2018), function as stepping stones towards the opening of "black box" of port governance by seeking and presenting general answers to the basic questions surrounding port governance. As to the future research, it is necessary to further check whether port governance has already been an accepted scientific paradigm in the port research domain. A scientific paradigm was defined by Kuhn (1996) as "universally recognized scientific achievements that, for a time, provide model problems and solutions for a community of practitioners". Pallis et al. (2010) once indicated that port research was situated in a pre-paradigmatic phase where low academic coherence existed. With the increasing number of studies on port governance in recent years, it is potentially feasible to conduct a more systematic review study from the view of paradigm to see whether there exist preconceptions commonly shared by port governance researchers. Inspired by Guba and Lincoln (1994), the mentioned future review study may specifically be conducted from ontological, epistemological and methodological perspectives to scrutinize the related studies.

\section{Ethical approval}

This article contains no study that was performed by any of the authors on human participants.

\section{Conflicts of interest}

Author Qiang Zhang declares that he has no conflict of interest. Author Shiyuan Zheng declares that he has no conflict of interest. Author Harry Geerlings declares that he has no conflict of interest. Author Abdel El Makhloufi declares that he has no conflict of interest.

\section{Funding}

This research is supported by the Shanghai Social Science Funding for Young Talents Program (2016EGL005), Chinese Ministry of
Education (MOE) Project of Humanities and Social Sciences (18YJCZH255), and Chinese National Natural Foundation Projects (71402095, 71774109, 71704103).

\section{References}

Bandara, Y.M., Nguyen, H.O., Chen, S.L., 2013. Determinants of port infrastructure pricing. Asian J. Shipp. Logist. 29 (2), 187-206.

Baltazar, R., Brooks, M.R., 2006. Port governance, devolution and the matching framework: a configuration theory approach. Res. Transport. Econ. 17, 379-403.

Brooks, M.R., 2004. The governance structure of ports. Rev. Netw. Econ. 3 (2), 168-183.

Brooks, M.R., 2016. Port governance as a tool of economic development: revisiting the question. In: Dynamic Shipping and Port Development in the Globalized Economy. Palgrave Macmillan, UK.

Brooks, M.R., 2017. A new direction or stay the course? Canada's port-specific challenges resulting from the port reform program of the 1990s. Res. Transp. Bus. Manag. 22, $161-170$.

Brooks, M.R., Cullinane, K., 2006. Governance models defined. Res. Transport. Econ. 17, 405-435.

Brooks, M.R., Cullinane, K., Pallis, A.A., 2017. Revisiting port governance and port reform: a multi-country examination. Res. Transp. Bus. Manag. 22, 1-10.

Brooks, M.R., Pallis, A.A., 2008. Assessing port governance models: process and performance components. Marit. Pol. Manag. 35 (4), 411-432.

Brooks, M.R., Pallis, A.A., 2012. Port Governance. The Blackwell Companion to Maritime Economics, pp. 491-516.

Brooks, M.R., Schellinck, T., 2015. Measuring port effectiveness: what really determines cargo interests' evaluations of port service delivery? Marit. Pol. Manag. 42 (7), 699-711.

Brooks, M.R., Schellinck, T., Pallis, A.A., 2011. A systematic approach for evaluating port effectiveness. Marit. Pol. Manag. 38 (3), 315-334.

Caldeirinha, V., Felício, J.A., Cunha, S.F.D., 2017. Government policies and Portuguese port governance in the period from 2005 to 2015. Res. Transp. Bus. Manag. 22, 11-20.

Caldeirinha, V., Felício, J.A., Cunha, S.F.D., Luz, L.M.D., 2018. The nexus between port governance and performance. Marit. Pol. Manag. 45 (7), 877-892.

Castillo-Manzano, J.I., Castro-Nuño, M., Fageda, X., Gonzalez-Aregall, M., 2016. Evaluating the effects of the latest change in Spanish port legislation: another "turn of the screw" in port reform? Case Stud. Transport Pol. 4 (2), 170-177.

Cepolina, S., Ghiara, H., 2013. New trends in port strategies. Emerging role for ICT infrastructures. Res. Transp. Bus. Manag. 8, 195-205.

Chen, H.C., Liu, S.M., 2015. Optimal concession contracts for landlord port authorities to maximize traffic volumes. Marit. Pol. Manag. 42 (1), 11-25.

Chen, P.S.L., Pateman, H., Sakalayen, Q., 2017. The latest trend in Australian port privatisation: drivers, processes and impacts. Res. Transp. Bus. Manag. 22, 201-213.

Coto-Millán, P., Fernández, X.L., Hidalgo, S., Pesquera, M.Á., 2016. Public regulation and technical efficiency in the Spanish port authorities: 1986-2012. Transport Pol. 47, $139-148$.

Cullinane, K., Song, D.W., 2002. Port privatization policy and practice. Transport Rev. 22 (1), 55-75.

Debrie, J., Gouvernal, E., Slack, B., 2007. Port devolution revisited: the case of regional ports and the role of lower tier governments. J. Transp. Geogr. 15 (6), 455-464.

Debrie, J., Lavaud-Letilleul, V., Parola, F., 2013. Shaping port governance: the territorial trajectories of reform. J. Transp. Geogr. 27, 56-65.

De Langen, P.W., Van der Lugt, L.M., 2017. Institutional reforms of port authorities in The Netherlands; the establishment of port development companies. Res. Transp. Bus. Manag. 22, 108-113.

Dooms, M., Verbeke, A., Haezendonck, E., 2013. Stakeholder management and path dependence in large-scale transport infrastructure development: the port of Antwerp case (1960-2010). J. Transp. Geogr. 27 (2), 14-25.

Eski, Y., 2016. The war on meaninglessness: a counter-terrorist self through an absent terrorist other. Ethnography 17 (4), 460-479.

Farrell, S., 2012. The ownership and management structure of container terminal concessions. Marit. Pol. Manag. 39 (1), 7-26.

Ferrari, C., Parola, F., Tei, A., 2015. Governance models and port concessions in Europe: commonalities, critical issues and policy perspectives. Transport Pol. 41, 60-67.

Galvão, C.B., Robles, L.T., Guerise, L.C., 2017. 20 years of port reform in Brazil: insights into the reform process. Res. Transp. Bus. Manag. 22, 153-160.

Ghashat, H.M., Cullinane, K.P., 2013. The future governance structure of Libya's container ports: a survey of stakeholder attitudes. Res. Transp. Bus. Manag. 8, 7-16.

Guba, E.G., Lincoln, Y.S., 1994. Competing paradigms in qualitative research. Handb. Qual. Res. 2, 105-117.

Ha, M.H., Yang, Z., Notteboom, T., Ng, A.K.Y., Heo, M.W., 2017. Revisiting port performance measurement: a hybrid multi-stakeholder framework for the modelling of port performance indicators. Transport. Res. E Logist. Transport. Rev. 103, 1-16.

Huo, W., Zhang, W., Chen, S.L., 2018. Recent development of Chinese port cooperation strategies. Res. Transp. Bus. Manag. 26, 67-75.

Knatz, G., 2017. How competition is driving change in port governance, strategic decision-making and government policy in the United States. Res. Transp. Bus. Manag. $22,67-77$.

Knatz, G., 2018. Port mergers: why not Los Angeles and long beach? Res. Transp. Bus Manag. 26, 26-33.

Kuhn, T.S., 1996. The Structure of Scientific Revolutions, third ed. University of Chicago Press, Chicago.

Lam, J.S.L., Ng, A.K., Fu, X., 2013. Stakeholder management for establishing sustainable 
regional port governance. Res. Transp. Bus. Manag. 8, 30-38.

Lam, J.S.L., Notteboom, T., 2014. The greening of ports: a comparison of port management tools used by leading ports in Asia and Europe. Transport Rev. 34 (2), 169-189.

Lambrou, M.A., Pallis, A.A., Nikitakos, N.V., 2008. Exploring the applicability of electronic markets to port governance. Int. J. Ocean Syst. Manag. 1 (1), 14-30.

Lee, P.T.W., Flynn, M., 2011. Charting a new paradigm of container hub port development policy: the Asian doctrine. Transport Rev. 31 (6), 791-806.

Liu, L., Wang, K.Y., Yip, T.L., 2013. Development of a container port system in Pearl River Delta: path to multi-gateway ports. J. Transp. Geogr. 28 (4), 30-38.

Mclaughlin, H., Fearon, C., 2013. Understanding the development of port and regional relationships: a new cooperation/competition matrix. Marit. Pol. Manag. 40 (3), 278-294.

Merkel, A., Holmgren, J., 2017. Dredging the depths of knowledge: efficiency analysis in the maritime port sector. Transport Pol. 60, 63-74.

Monios, J., 2017. Port governance in the UK: planning without policy. Res. Transp. Bus. Manag. 22, 78-88.

Notteboom, T., 2006. Concession agreements as port governance tools. Res. Transport. Econ. 17, 437-455.

Notteboom, T., Pallis, A.A., Farrell, S., 2012. Terminal concessions in seaports revisited. Marit. Pol. Manag. 39 (1), 1-5.

Notteboom, T., Parola, F., Satta, G., Penco, L., 2015. Disclosure as a tool in stakeholder relations management: a longitudinal study on the port of Rotterdam. Int. J. Logist. Res. Appl. 18 (3), 228-250.

Notteboom, T., Rodrigue, J.P., 2005. Port regionalization: towards a new phase in port development. Marit. Pol. Manag. 32 (3), 297-313.

Notteboom, T., Knatz, G., Parola, F., 2018. Port co-operation: types, drivers and impediments. Res. Transp. Bus. Manag. 26, 1-4.

Notteboom, T., Yang, Z., 2017. Port governance in China since 2004: institutional layering and the growing impact of broader policies. Res. Transp. Bus. Manag. 22, 184-200.

Pagano, A.M., Wang, G.W.Y., Sánchez, O.V., Ungo, R., 2013. Impact of privatization on port efficiency and effectiveness: results from Panama and US ports. Marit. Pol. Manag. 40 (2), 100-115.

Pallis, A.A., Vitsounis, T.K., Langen, P.W.D., 2010. Port economics, policy and management: review of an emerging research field. Transport Rev. 30 (1), 115-161.

Panayides, P.M., Lambertides, N., Andreou, C., 2017. Reforming public port authorities through multiple concession agreements: the case of Cyprus. Res. Transp. Bu. Manag. 22, 58-66.

Parola, F., Ferrari, C., Tei, A., Satta, G., Musso, E., 2017. Dealing with multi-scalar embeddedness and institutional divergence: evidence from the renovation of Italian port governance. Res. Transp. Bus. Manag. 22, 89-99.

Rodrigue, J.P., Notteboom, T., 2010. Foreland-based regionalization: integrating intermediate hubs with port hinterlands. Res. Transport. Econ. 27, 19-29.

Serebrisky, T., Sarriera, J.M., Suárez-Alemán, A., Araya, G., Briceño-Garmendía, C.,
Schwartz, J., 2016. Exploring the drivers of port efficiency in Latin America and the Caribbean. Transport Pol. 45, 31-45.

Shinohara, M., Saika, T., 2018. Port governance and cooperation: the case of Japan. Res. Transp. Bus. Manag. 26, 56-66.

Song, D.W., 2003. Port co-opetition in concept and practice. Marit. Pol. Manag. 30 (1), 29-44.

Sorour, K., Abdul-Mageed, L., 2016. Enabling better port governance in developing countries: the role of information technology. In: Dey, B. (Ed.), ICTs in Developing Countries. Palgrave Macmillan, UK, pp. 171-189.

Talley, W.K., 2006. Port performance: an economics perspective. Res. Transport. Econ. 17, 499-516.

Valleri, M.A., 2005. Port governance and security. In: Maritime Heritage and Modern Ports, pp. 279-289.

Van Donselaar, P.W., Kolkman, J., 2010. Societal costs and benefits of cooperation between port authorities. Marit. Pol. Manag. 37 (3), 271-284.

Van de Voorde, E., Verhoeven, P., 2017. Port governance and policy changes in Belgium 2006-2016: a comprehensive assessment of process and impact. Res. Transp. Bus. Manag. (22), 123-134.

Van der Lugt, L.M., De Langen, P.W., Hagdom, L., 2017. Strategic beliefs of port authorities. Transport Rev. 37 (4), 412-435.

Verhoeven, P., 2010. A review of port authority functions: towards a renaissance? Marit. Pol. Manag. 37 (3), 247-270.

Verhoeven, P., Vanoutrive, T., 2012. A quantitative analysis of European port governance. Marit. Econ. Logist. 14 (2), 178-203.

Vieira, G.B.B., Kliemann Neto, F.J., Amaral, F.G., 2014. Governance, governance models and port performance: a systematic review. Transport Rev. 34 (5), 645-662.

Wang, C., Ducruet, C., Wang, W., 2015. Port integration in China: temporal pathways, spatial patterns and dynamics. Chin. Geogr. Sci. 25 (5), 612-628.

Wang, J.J., Ng, K.Y., Olivier, D., 2004. Port governance in China: a review of policies in an era of internationalizing port management practices. Transport Pol. 11, 237-250.

Wilmsmeier, G., Monios, J., 2016. Institutional structure and agency in the governance of spatial diversification of port system evolution in Latin America. J. Transp. Geogr. 51, 294-307.

Woo, S.H., Pettit, S.J., Kwak, D.W., Beresford, A.K.C., 2011. Seaport research: a structured literature review on methodological issues since the 1980s. Transport. Res. Pol. Pract. 45, 667-685.

Wu, S., Yang, Z., 2018. Analysis of the case of port co-operation and integration in Liaoning (China). Res. Transp. Bus. Manag. 26, 18-25.

Yoshitani, T., 2018. PNW seaport alliance: stakeholder's benefits of port cooperation. Res. Transp. Bus. Manag. 26, 14-17.

Zhang, Q., Geerlings, H., Makhloufi, A.E., Chen, S., 2018. Who governs and what is governed in port governance: a review study. Transport Pol. 64 (64), 51-60.

Zheng, S., Yin, C., 2015. Technical, allocative and cost efficiencies of Chinese ports. Marit. Pol. Manag. 42 (8), 746-758. 